\title{
Impact of Landscape and Season on the Ecological Distribution of Tabanidae and Stomoxyinae, Mechanical Vectors of Bovine Trypanosomosis in the Forest of Sanaga Maritime and Savanna of Ngaoundere, Cameroon
}

\author{
Andre Sieumeni Djonguep \\ Universite de Ngaoundere \\ Abdoulmoumini Mamoudou \\ Universite de Ngaoundere \\ Victor Dermy Hiol \\ Universite de Ngaoundere \\ Oumarou Lebalé \\ Universite de Ngaoundere \\ Silas Lendzele Sevidzem \\ Post Graduate school of higher institutes \\ Lisette Tongue Kohagne \\ Fight against parasitoses Association \\ Adler Cornel \\ Julius Kuhn Institute \\ Elias Nchiwan Nukenine ( $\nabla$ ennukenine@fulbrightmail.org) \\ Universite de Ngaoundere
}

\section{Research}

Keywords: Tabanids, Stomoxyines, Landscape, Season, Sanaga, Cameroon

Posted Date: July 19th, 2021

DOI: https://doi.org/10.21203/rs.3.rs-713435/v1

License: (c) (i) This work is licensed under a Creative Commons Attribution 4.0 International License. Read Full License 


\section{Abstract}

Background: Huge pasture areas in sub-Saharan Africa are heavily infested by tabanids and stomoxyines whose distribution across season and in different landscape differs and is poorly described in Cameroon.

Methods: A longitudinal entomological prospection (January 2017 to December 2017) was carried out in the savanna of Ngaoundere and forest of the Sanaga Maritime of Cameroon, using three trap-types (Nzi, Biconical and Vavoua). A total of 18 traps were used in this study with nine in each site.

Results: In the forest, 44317 Stomoxys belonging to four species were captured with an apparent density of 136.78 flies per trap and day $(\mathrm{f} / \mathrm{t} / \mathrm{d})$. Twelve species of tabanids were collected with 3524 individuals with an apparent density of $10.87 \mathrm{f} / \mathrm{t} / \mathrm{d}$. Stomoxys niger niger was the most abundant species while for tabanids, Tabanus taeniola (48.63\%) was most represented. In the savanna, $4501(13.89 \mathrm{f} / \mathrm{t} / \mathrm{d})$ Stomoxys were collected and regrouped under five species with $S$. n. niger $(70.91 \%)$ highly represented and $547(1.68 \mathrm{f} / \mathrm{t} / \mathrm{d})$ tabanids collected and regrouped under 10 species with Tabanus taeniola as the most dominant species. Trap apparent density (ADT) varied with sampled sites, seasons and the prevailing weather conditions in the forest and savanna.

Conclusion: From the present finding, it can be deduced that $T$. taeniola and $S$. $n$. niger were the most abundant and indicate the risk of mechanical transmission of dangerous pathogens such as bovine trypanosomosis.

\section{Background}

Hematophagous dipterous insects are temporal ectoparasites of domestic, wild animals and sometimes man [1]. They are of great medical and veterinary importance because the diseases they transmit are principal causes of morbidity and mortality in several tropical and subtropical countries [2]. Amongst these dipterans, tabanids and stomoxyines are of great importance due to their direct and indirect impact on hosts [3]. More specifically, stomoxyines and tabanids constitute a real nuisance for livestock and are responsible for the mechanical and/or biological transmission of pathogenic agents such as bacteria and protozoa [4].

In Africa, studies on the abundance and spatio-temporal variation of tabanids and stomoxyines have been carried out in several countries and have led to the description of several species [5-11]. In Cameroon, research on these vectors is rather incomplete. Preliminary studies on these fly-vectors were carried out by Rageau et al. [12] who reported 60 different species of tabanids in forest zones, followed by that of Ovazza et al. [13] who equally reported close to 100 species. More than 40 years later, the only published date are those of Sevidzem et al. [14-15], Lendzele et al. [16] and Mamoudou et al. [17] who reported the occurrence of high numbers of members of the family Tabanidae and Stomoxyidae at the livestock/wildlife interface of the Adamawa plateau of Cameroon. The work of Sieumeni et al. [18] revealed three species of tabanids and two species of stomoxyines. The preliminary work [15] revealed the occurrence of four species of stomoxyines in the north savanna as well as six species of tabanids. Lendzele et al. [16] and most recently, Mounioko et al. [19] identified five species of stomoxyines and four species of tabanids in the southern rainforest region of Cameroon.

The influence of weather variables on the distribution of tabanids and stomoxyines has been reported [20-24]. It was noticed that weather variables such as temperature, humidity and windspeed can influence the distribution and the diurnal activity of stomoxyines and tabanids. In sub-Saharan Africa, the influence of weather variables on the monthly distribution and diurnal activity rhythm of tabanids and stomoxyines have been poorly studied. Thus, considering the effect that such climatic conditions can have on the monthly and daily dynamics of tabanids and stomoxyines, it is important to consider them when studying their abundance in different bioclimatic zones. 
The previous works on tabanids and stomoxyines of Cameroon were transversal, but the present study will fill the gap by presenting data on a longitudinal and comparative follow-up study of the population of tabanids and stomoxyines in the forest of Sanaga Maritime and savanna of Ngaoundere in Cameroon. The first objective was to study the biodiversity of tabanids and stomoxyines in the forest and savanna. The second objective was to study the monthly abundance of tabanids and Stomoxyines in the forest and savanna as well as the influence of weather variables (temperature, humidity and rainfall) on their abundance.

\section{Methods}

\section{Study area}

The study was carried out in the Sanaga Maritime Division and in Ngaoundere from January to December 2017. The Sanaga Maritime zone is situated between Latitude $4^{\circ} 0^{\prime} \mathrm{N}$ and longitude $10^{\circ} 19^{\prime} \mathrm{E}$. Its climate is of the Guinean equatorial type and it is characterized by two seasons notably rainy season (March to October) and dry season (November to February). Annual precipitations range between 1500 to $2000 \mathrm{~mm}$. Minimum average temperature was $22.5^{\circ} \mathrm{C}$ in July and maximum average temperature was $34.6^{\circ} \mathrm{C}$ in April. It is situated at an altitude of $35 \mathrm{~m}$ a.s.I with a vast hydrographic network of which river Sanaga is one of the most important rivers [25]. The wildlife fauna is well represented; due to the presence of the Douala-Edea Forest Reserve (DEFR) that houses several animal species. Avian fauna consists of an impressive variety of endemic birds that attract many western researchers and tourists [26]. The study sites in the forest of Sanaga consisted of the abattoir (open forest), palm oil plantation (open forest with mainly tall palm trees) and game reserve (humid and closed forest with tall canopy trees). The Adamawa plateau that harbors Ngaoundere, extends across the middle of the country and lays between latitudes $6^{\circ}$ and $8^{\circ}$ North and longitude $11^{\circ}$ and $15^{\circ}$ East and is elevated at an altitude of about $1000 \mathrm{~m}$ a.s.I. It possesses a Soudan-Guinean climate with mean temperature of $25^{\circ} \mathrm{C}$ in the cold season and $31^{\circ} \mathrm{C}$ in the hot season. There are two seasons, rainy (May to October) and dry (November to April). The annual rainfall in the rainy season is $1500 \mathrm{~mm}$. The vegetation of Ngaoundere is made of open grass savanna, gallery and secondary forests. The savanna is densely covered by Daniellia oliveri and Lophira lanceolata [27]. The hydrograhic network consist of an important water body known as river Vina and some other secondary rivers. The sites in Ngaoundere consisted of Velambai (lake Djalingo with open grass savanna), Mbidjoro (open grass savanna, forestsavanna mosaic) and Vina du Sud (river Vina with gallery forest).

\section{Method of fly-collection}

Three sites were identified in each study area that represented the trapping sites. In the forest of Sanaga, the prospection sites consisted of the abattoir, palm oil plantation and around the Game reserve. While the sites in Ngaoundere consisted of Velambai, Mbidjoro and Vina du Sud. These sites were selected based on the characteristics of the trapping milieu (fly

breeding sites and areas frequented by cattle and wildlife). Tabanid and stomoxyines were captured using three different traps (Biconical, Vavoua and Nzi, N = 18). The use of three different traps was to maximize the chance of getting different species of the target population. Each of the three trap-types was pitched in one of the sites (i.e. each study area consisted of three different traps and each micro-environment in the study areas consisted of one trap-type with rotations carried out daily) and monitored three days consecutively every month for 12 months. Trap exposition period was from morning $(7 \mathrm{~h})$ to evening $(18 \mathrm{~h})$. The readings of the monthly temperature, humidity and precipitation was collected from the weather station of Ngaoundere and Douala. The trapping effort was determined by the number of traps installed by day in the sites during trapping period as such: 18 traps $\times 3(12) \times 6$ sites in the two sampled areas $=$ 3888 traps days.

\section{Fly Identification}


The identification of stomoxyines was carried out using the identification key developed by Zumpt [28]. For tabanids, the identification keys of Surcouf and Ricardo [29] and type- specimens published by Desquesnes et al. [30] were used.

\section{Data analyses}

The abundance of trapped flies was defined by their apparent density per trap and day.

$$
\mathrm{ADT}=\frac{\text { number of tabanids or stomoxyines captured }}{\text { number of traps } \times \text { number of days }}
$$

The quantification of the biodiversity of trapped tabanids and stomoxyines was determined using various biodiversity indices. To quantify the heterogeneity of the biodiversity of the trapped flies in the study area, the Shannon's diversity index was applied as follows:

$\mathrm{H}^{\prime}=-\Sigma(\mathrm{Ni} / \mathrm{N}) \times \ln (\mathrm{Ni} / \mathrm{N})$

Where $\mathrm{Ni}=$ number of individuals of a given species

$\mathrm{N}=$ total number of individuals

The Margalef index (I) was determined and this index is based on the logarithmic growth of species (S) is considered as a function of the log of the individuals examined. It is an indicator of the species richness [31]:

$$
(\mathrm{I})=\frac{(\mathrm{S}-1)}{\log \mathrm{N}}
$$

The Piélou Equitability Index, also known as the Equity Distribution Index (EDI), was calculated according to the formula:

$$
(E)=\frac{I s h}{\log (S)}
$$

Where $S$, is the number of species.

The Krustall-Wallis non-parametric test was carried out to compare the distribution of different species trapped from the three study sites in the two seasons. The pearson's correlation test was used to compare the monthly ADT of tabanids and stomoxyines with weather variables in the various sites. All statistical tests were carried out using Statgraphics centurion XVII and SPSS version 16.0 software. The statistical significance level was kept at $p<0.05$.

\section{Results}

\section{Stomoxyines and tabanids species composition, distribution and diversity in the forest}

In the forest, 47841 hematophagous flies were caught, resulting in a mean ADT of $147.66 \mathrm{f} / \mathrm{t} / \mathrm{d}$. Stomoxyines were more abundant with 44317 collected and 3524 tabanids captured, resulting in ADTs of 136.78 and $10.87 \mathrm{f} / \mathrm{t} / \mathrm{d}$ respectively. Four species of Stomoxys were identified. Stomoxys niger niger and Stomoxys omega were most represented with $63.58 \%$ and $29.54 \%$ respectively whilst Stomoxys calcitrans (3.09\%) was the least represented (Table 1). Twelve species of tabanids belonging to four genera were identified, the genus Tabanus (92.90\%) was the most frequent while the genus Ancala (0.53\%) was the least frequent. Tabanus taeniola and Tabanus par were the most abundant with proportion of 
$48.63 \%$ and $38.62 \%$ respectively, while the least represented species was Tabanus argenteus with $0.28 \%$ catches (Table 1). The Shannon diversity index was 1.16 and the Piélou index was 0.42 . One species of the genus Chrysops and one species of the genus Tabanus could not be identified due to the lack of information about this specimen in the identification keys. 
Table 1

Species composition of stomoxyids and tabanids with prospection sites

\begin{tabular}{|c|c|c|c|c|c|c|c|c|}
\hline Family & Genus & Species & Number & $(\%)$ & $\mathrm{ADT} \pm \mathrm{SE}$ & & & $\begin{array}{l}\mathrm{P} \text { - } \\
\text { value }\end{array}$ \\
\hline Forest & & & & & Abattoir & $\begin{array}{l}\text { Palm oil } \\
\text { plantation }\end{array}$ & $\begin{array}{l}\text { Game } \\
\text { reserve }\end{array}$ & \\
\hline \multirow[t]{5}{*}{$\begin{array}{l}\text { Stomoxyidae( } \mathbf{N} \\
=\mathbf{4 4 3 1 7})\end{array}$} & & S. niger & 28180 & 63.58 & $\begin{array}{l}225.60 \\
\pm 57.97\end{array}$ & $\begin{array}{l}31.75 \pm \\
12.06\end{array}$ & $\begin{array}{l}3.56 \pm \\
0.95\end{array}$ & $\star \star \star *$ \\
\hline & & S. omega & 13092 & 29.54 & $\begin{array}{l}36.78 \pm \\
17.20\end{array}$ & $\begin{array}{l}79.01 \pm \\
30.58\end{array}$ & $\begin{array}{l}5.41 \pm \\
1.42\end{array}$ & * \\
\hline & & S.xanthomelas & 1675 & 3.77 & $\begin{array}{l}13.64 \pm \\
3.58\end{array}$ & $\begin{array}{l}1.15 \pm \\
0.56\end{array}$ & $\begin{array}{l}0.7 \pm \\
0.26\end{array}$ & $\star \star \star$ \\
\hline & & S. calcitrans & 1370 & 3.09 & $\begin{array}{l}5.86 \pm \\
0.93\end{array}$ & $\begin{array}{l}5.64 \pm \\
1.57\end{array}$ & $\begin{array}{l}1.17 \pm \\
0.26\end{array}$ & * \\
\hline & Stomoxys & Total & 44317 & 100 & $\begin{array}{l}281.89 \\
\pm 59.63\end{array}$ & $\begin{array}{l}117.58 \pm \\
41.84\end{array}$ & $\begin{array}{l}10.86 \\
\pm 2.41\end{array}$ & ** \\
\hline \multirow[t]{13}{*}{$\begin{array}{l}\text { Tabanidae }(\mathbf{N}= \\
\text { 3524) }\end{array}$} & Tabanus & T. taeniola & 1714 & 48.63 & $\begin{array}{l}0.75 \pm \\
0.60\end{array}$ & $\begin{array}{l}12.02 \pm \\
3.45\end{array}$ & $\begin{array}{l}3.09 \pm \\
1.01\end{array}$ & * \\
\hline & & T. par & 1361 & 38.62 & $\begin{array}{l}1.19 \pm \\
0.78\end{array}$ & $\begin{array}{l}7.92 \pm \\
2.33\end{array}$ & $\begin{array}{l}3.48 \pm \\
1.67\end{array}$ & ns \\
\hline & & T. socius & 114 & 3.23 & $\begin{array}{l}0.50 \pm \\
0.33\end{array}$ & $\begin{array}{l}0.27 \pm \\
0.17\end{array}$ & $\begin{array}{l}0.26 \pm \\
0.22\end{array}$ & ns \\
\hline & & T. latipes & 26 & 0.73 & $\begin{array}{l}0.00 \pm \\
0.00\end{array}$ & $\begin{array}{l}0.24 \pm \\
0.18\end{array}$ & $\begin{array}{l}0.00 \pm \\
0.00\end{array}$ & * \\
\hline & & T. argenteus & 10 & 0.28 & $\begin{array}{l}0.00 \pm \\
0.00\end{array}$ & $\begin{array}{l}0.09 \pm \\
0.07\end{array}$ & $\begin{array}{l}0.00 \pm \\
0.00\end{array}$ & * \\
\hline & & Tabanus sp & 49 & 1.39 & $\begin{array}{l}0.00 \pm \\
0.00\end{array}$ & $\begin{array}{l}0.45 \pm \\
0.30\end{array}$ & $\begin{array}{l}0.00 \pm \\
0.00\end{array}$ & * \\
\hline & Chrysops & C. longicornis & 108 & 3.06 & $\begin{array}{l}0.51 \pm \\
0.09\end{array}$ & $\begin{array}{l}0.12 \pm \\
0.06\end{array}$ & $\begin{array}{l}0.12 \pm \\
0.14\end{array}$ & * \\
\hline & & C. dimidiata & 55 & 1.56 & $\begin{array}{l}0.27 \pm \\
0.05\end{array}$ & $\begin{array}{l}0.19 \pm \\
0.09\end{array}$ & $\begin{array}{l}0.03 \pm \\
0.02\end{array}$ & * \\
\hline & & C. silacea & 23 & 0.65 & $\begin{array}{l}0.05 \pm \\
0.03\end{array}$ & $\begin{array}{l}0.12 \pm \\
0.07\end{array}$ & $\begin{array}{l}0.02 \pm \\
0.02\end{array}$ & ns \\
\hline & Ancala & A.fasciata & 19 & 0.53 & $\begin{array}{l}0.00 \pm \\
0.00\end{array}$ & $\begin{array}{l}0.17 \pm \\
0.10\end{array}$ & $\begin{array}{l}0.00 \pm \\
0.00\end{array}$ & * \\
\hline & Haematopota & H. decora & 28 & 0.79 & $\begin{array}{l}0.02 \pm \\
0.01\end{array}$ & $\begin{array}{l}0.17 \pm \\
0.12\end{array}$ & $\begin{array}{l}0.05 \pm \\
0.05\end{array}$ & ns \\
\hline & & $\begin{array}{l}\text { Haematopota } \\
s p\end{array}$ & 17 & 0.48 & $\begin{array}{l}0.04 \pm \\
0.37\end{array}$ & $\begin{array}{l}0.08 \pm \\
0.05\end{array}$ & $\begin{array}{l}0.02 \pm \\
0.02\end{array}$ & ns \\
\hline & & Total & 3524 & 100 & $\begin{array}{l}3.37 \pm \\
1.73\end{array}$ & $\begin{array}{l}21.90 \pm \\
5.46\end{array}$ & $\begin{array}{l}7.34 \pm \\
2.59\end{array}$ & ns \\
\hline Savanna & & & & & Mbidjoro & Velambaï & $\begin{array}{l}\text { Vina } \\
\text { du sud }\end{array}$ & \\
\hline
\end{tabular}

ns $=$ non significant $=\mathrm{P}>0.05, * \mathrm{P}<0.05$, * $\mathrm{P}<0.001$, ** $\mathrm{P}<0.0001, \mathrm{ADT}$ apparent density, SE standard error 


\begin{tabular}{|c|c|c|c|c|c|c|c|c|}
\hline Family & Genus & Species & Number & $(\%)$ & \multicolumn{3}{|c|}{$\mathrm{ADT} \pm \mathrm{SE}$} & $\begin{array}{l}\mathrm{P} \text { - } \\
\text { value }\end{array}$ \\
\hline \multirow[t]{6}{*}{$\begin{array}{l}\text { Stomoxyidae( } \mathbf{N} \\
=\mathbf{4 5 0 1})\end{array}$} & & S. niger & 3192 & 70.91 & $\begin{array}{l}10.08 \pm \\
2.44\end{array}$ & $\begin{array}{l}4.50 \pm \\
1.08\end{array}$ & $\begin{array}{l}14.97 \\
\pm 5.17\end{array}$ & ns \\
\hline & & S. omega & 418 & 9.28 & $\begin{array}{l}2.13 \pm \\
1.15\end{array}$ & $\begin{array}{l}0.63 \pm \\
0.37\end{array}$ & $\begin{array}{l}1.09 \pm \\
0.48\end{array}$ & ns \\
\hline & & $\begin{array}{l}\text { S. } \\
\text { xanthomelas }\end{array}$ & 50 & 1.11 & $\begin{array}{l}0.10 \pm \\
0.03\end{array}$ & $\begin{array}{l}0,01 \pm \\
0.01\end{array}$ & $\begin{array}{l}0.35 \pm \\
0.12\end{array}$ & * \\
\hline & & S. calcitrans & 834 & 18.52 & $\begin{array}{l}2.15 \pm \\
0.62\end{array}$ & $\begin{array}{l}1.25 \pm \\
0.34\end{array}$ & $\begin{array}{l}4.31 \pm \\
1.59\end{array}$ & ns \\
\hline & Stomoxys & S. inornatus & 7 & 0.15 & $\begin{array}{l}0.00 \pm \\
0.00\end{array}$ & $\begin{array}{l}0.00 \pm \\
0.00\end{array}$ & $\begin{array}{l}0.06 \pm \\
0.06\end{array}$ & ns \\
\hline & & Total & 4501 & 100 & $\begin{array}{l}14.48 \pm \\
3.57\end{array}$ & $\begin{array}{l}6.39 \pm \\
1.60\end{array}$ & $\begin{array}{l}20.79 \\
\pm 6.60\end{array}$ & ns \\
\hline \multirow[t]{11}{*}{$\begin{array}{l}\text { Tabanidae }(\mathbf{N}= \\
\text { 547) }\end{array}$} & Tabanus & T. taeniola & 176 & 32.17 & $\begin{array}{l}0.35 \pm \\
0.20\end{array}$ & $\begin{array}{l}0.50 \pm \\
0.17\end{array}$ & $\begin{array}{l}0.76 \pm \\
0.37\end{array}$ & ns \\
\hline & & T.par & 81 & 14.80 & $\begin{array}{l}0.26 \pm \\
0.13\end{array}$ & $\begin{array}{l}0.20 \pm \\
0.10\end{array}$ & $\begin{array}{l}0.27 \pm \\
0.16\end{array}$ & ns \\
\hline & & T. gratus & 11 & 2.01 & $\begin{array}{l}0.01 \pm \\
0.01\end{array}$ & $\begin{array}{l}0.00 \pm \\
0.00\end{array}$ & $\begin{array}{l}0.09 \pm \\
0.05\end{array}$ & ns \\
\hline & & T. ricardae & 13 & 2.37 & $\begin{array}{l}0.00 \pm \\
0.00\end{array}$ & $\begin{array}{l}0.05 \pm \\
0.37\end{array}$ & $\begin{array}{l}0.07 \pm \\
0.05\end{array}$ & ns \\
\hline & & T. fasciatus & 2 & 0.36 & $\begin{array}{l}0.00 \pm \\
0.00\end{array}$ & $\begin{array}{l}0.00 \pm \\
0.00\end{array}$ & $\begin{array}{l}0.02 \pm \\
0.02\end{array}$ & ns \\
\hline & Chrysops & C. longicornis & 103 & 18.82 & $\begin{array}{l}0.53 \pm \\
0.18\end{array}$ & $\begin{array}{l}0.06 \pm \\
0.02\end{array}$ & $\begin{array}{l}0.35 \pm \\
0.02\end{array}$ & ns \\
\hline & & $\begin{array}{l}\text { C. } \\
\text { distinctipennis }\end{array}$ & 115 & 21.02 & $\begin{array}{l}0.31 \pm \\
0.20\end{array}$ & $\begin{array}{l}0.23 \pm \\
0.12\end{array}$ & $\begin{array}{l}0.51 \pm \\
0.38\end{array}$ & ns \\
\hline & Ancala & A. fasciata & 17 & 3.10 & $\begin{array}{l}0.00 \pm \\
0.00\end{array}$ & $\begin{array}{l}0.00 \pm \\
0.00\end{array}$ & $\begin{array}{l}0.15 \pm \\
0.14\end{array}$ & ns \\
\hline & Haematopota & H. decora & 24 & 4.38 & $\begin{array}{l}0.06 \pm \\
0.06\end{array}$ & $\begin{array}{l}0.02 \pm \\
0.27\end{array}$ & $\begin{array}{l}0.12 \pm \\
0.09\end{array}$ & ns \\
\hline & Atylotus & A.agrestis & 5 & 0.91 & $\begin{array}{l}0.02 \pm \\
0.10\end{array}$ & $\begin{array}{l}0.00 \pm \\
0.00\end{array}$ & $\begin{array}{l}0.01 \pm \\
0.01\end{array}$ & ns \\
\hline & & Total & 547 & 100 & $\begin{array}{l}1.57 \pm \\
0.45\end{array}$ & $\begin{array}{l}1.08 \pm \\
0.31\end{array}$ & $\begin{array}{l}2.40 \pm \\
0.96\end{array}$ & ns \\
\hline
\end{tabular}

Stomoxyines and tabanids species composition, diversity and distribution in the savanna 
In the savanna, 5048 haematophagous flies were caught with mean ADT of 15.58. Here, 4501 stomoxyines (89.16\%) were collected with ADT of $13.89 \mathrm{f} / \mathrm{t} / \mathrm{d}$ and 547 tabanids (10.83\%) were caught with ADT of 1.68f/t/d. Five species of stomoxyines were identified with S. n. niger (70.91\%) as the most frequent species; while Stomoxys inornatus (0.15\%) was rare. Ten species of tabanids belonging to five genera were recorded and the genus Tabanus (51.73\%) was highly represented while the genus Ancala (3.10\%) was rare. Similarly, T. taeniola (32.17) was the most represented species while Tabanus fasciatus ( $0.36 \%$ ) was rare. The Shannon diversity index was 1.28 in the savanna and the equity distribution index of Piélou was 0.47 (Table 1).

\section{Variation in the abundance of hematophagous flies across sampling sites in the forest}

All species of stomoxyines were represented in all the sites prospected and this was not the case for tabanids. Highest catches were recorded at the Abattoir (60.40\%) and lowest in the Game Reserve (4.10\%). Trap apparent density for stomoxyines differed significantly between sites (Pख0.001 and $F=10.53)$ and the highest was observed at the abattoir with $A D T$ of $28.89 \mathrm{f} / \mathrm{t} / \mathrm{d}$. For tabanids, the ADT was significantly higher in the palm oil plantation $(21.90 \mathrm{f} / \mathrm{t} / \mathrm{d} ; \mathrm{P} \otimes 0.05 \mathrm{and}$ $F=7.20)$ and the lowest ADT was observed at the abattoir $(3.37 \mathrm{f} / \mathrm{t} / \mathrm{d})$. In the three sampled sites, $S$. $n$. niger was the most abundant species and consisted of $60 \%$ of the total catches (Table 1). For tabanids, $T$. taeniola $(F=7.97,12.02$ $\mathrm{f} / \mathrm{t} / \mathrm{d})$ and $T . \operatorname{par}(F=3.95,7.92 \mathrm{f} / \mathrm{t} / \mathrm{d})$ were frequent in the palm oil plantation, while $C$. longicornis $(F=3.34,0.51 \mathrm{f} / \mathrm{t} / \mathrm{d})$ and $C$. dimidiata $(F=3.58,0.27 \mathrm{f} / \mathrm{t} / \mathrm{d})$ were the most abundant at the abattoir. $T$. argenteus, $T$. latipes and $A$. fasciata were only present at the palm oil plantation. For stomoxyines, S. n. niger (225.60 snn/t/d) and S. xanthomelas (13.64 $\mathrm{sx} / \mathrm{t} / \mathrm{d})$ were most abundant at the abattoir with a statistically significant difference (Pख0.05) between the two species, while $S$. omega and $S$. calcitrans were frequent at the abattoir and palm oil plantation with a statistically significant difference (Pख0.05). The highest species diversity was noticed in the Game reserve and lowest diversity was recorded at the abattoir. For stomoxyines, $H^{\prime}$ was higher in the Game reserve $\left(H^{\prime}=1.3\right)$ and lower at the abattoir $\left(H^{\prime}=0.67\right)$ while for tabanids, the species diversity index was higher at the abattoir (1.64) and lower around the Game reserve (1.09).

\section{Variation in the abundance of hematophagous flies across sampling sites in savanna}

The ADT of stomoxyines did not differ statistically $(\mathrm{P}>0.05 ; F=2.65)$ and a similar non statistically significant difference $(P>0.05 ; F=1.09)$ in the ADT of tabanids with site was also noticed. However, the ADT of stomoxyines (20.79 $\mathrm{f} / \mathrm{t} / \mathrm{d}$ ) and that of tabanids $(2.4 \mathrm{f} / \mathrm{t} / \mathrm{d}$ ) was highest in Vina du Sud and least in Vélambai with ADT of $6.39 \mathrm{f} / \mathrm{t} / \mathrm{d}$ for stomoxyines and $1.08 \mathrm{f} / \mathrm{t} / \mathrm{d}$ for tabanids. The diversity index of Shannon was weak in Vina du sud (0.8) and very strong in Mbidjoro (0.85). S. xanthomelas is the only species that differed significantly $(F=5,32 ; \mathrm{DAP}=0,35 \pm 0,12 \mathrm{~S} / \mathrm{P} / \mathrm{J})$ with site and dominant in Vina du sud. However, $S$. n. niger $14.97 \mathrm{f} / \mathrm{t} / \mathrm{d}$ and $S$. calcitrans $4.31 \mathrm{f} / \mathrm{t} / \mathrm{d}$ were most frequent in Vina du Sud while $S$. omega $(2.13 \mathrm{f} / \mathrm{t} / \mathrm{d})$ was dominat in Mbidjoro. $S$. inornatus was only caught in Vina du sud. For tabanids, most species were abundant in Vina du sud and some of such frequent species consisted of $T$. taeniola $(0.76 \mathrm{f} / \mathrm{t} / \mathrm{d}), T$. $\operatorname{par}(0.27 \mathrm{f} / \mathrm{t} / \mathrm{d})$ and $C$. distinctipennis $(0.51 \mathrm{f} / \mathrm{t} / \mathrm{d})$, while $C$. longicornis $(0.53 \mathrm{f} / \mathrm{t} / \mathrm{d})$ was dominant in Mbidjoro. Certain species of tabanids such as $T$. gratus and $A$. agrestis were not caught in other sites like Vélambaï. T. fasciatus and $A$. fasciata were only present in Vina du sud (Table 1$)$. The species diversity $\left(H^{\prime}=1.86\right)$ of tabanids was high in Vina du sud and lower in Vélambaï (1.39). The stomoxyines species diversity $\left(H^{\prime}=0.8\right)$ was lower in Vina du sud and higher in Mbidjoro (0.85).

\section{Monthly variation of stomoxyines and tabanids in the forest}

In general, the ADT of tabanids did not differ significantlhy $(F=1.73 ; \mathrm{P}>0.05)$ with trapping months. Also, there was a non statitistically significant difference $(F=1.05 ; \mathrm{P}>0.05)$ in the monthly collection of stomoxyines. Peak monthly 
catches for tabanids (25\%) were observed in December while scanty catch (1\%) was noticed in August. For stomoxyines, peak catch (19\%) was noticed in August and minimum (1\%) in February (Fig. 1).

It was noticed that no tabanid species was consistently present throughout the collection period in the different sites. Thus, T. parwas significantly present in all the sites in December and $C$. Iongicornis occurred in all the sites in April. On the contrary, T. taeniola showed several peaks in the same month or in different months i.e. two peaks in February and December at the abattoir and Game reserve, three peaks in February, May and December at the palm oil plantation. On the other hand, certain species showed a weak frequency throughout the year in different sites (Fig. 2) and such cases included $\mathrm{H}$. decora that was only observed in the month of January and February at the Abattoir and palm oil plantation, but in the Game reserve it only appeared in February. T. latipes and T. argenteus was only present in May and June and was only present in the palm oil plantation. The tabanid species richness was very high in May with eight species recorded resulting in Margalef diversity index of 2.57 and was very low in September (1.0) where only two species were recorded.

The ADT of stomoxyines fluctuated between months and as a function of site. Thus, the abundance peak of $S$. $n$. niger was observed in September at the abattoir and in July at the palm oil plantation. In the Game reserve, three abundance peaks were noticed in August, May and February. Stomoxys calcitrans showed its peak at the abattoir and game reserve, while in the palm oil plantation, its peak occurred in August. S. xanthomelas was most abundant in May in all the sites except at the abattoir where its annual activity was bimodal with a second abundance peak in September. The stomoxyines species richness was similar in all the prospection months; while the Margalef index was high in February (1.17) and low in August (0.76).

\section{Monthly variation of stomoxyines and tabanids in the savanna}

The overall ADT of tabanids differed significantly $(F=2.99 ; \mathrm{P} \otimes 0.05)$ with collection months. The maximum number of catches was observed in March with $31 \%$ of the catches while minimum record was witnessed in July ( $1 \%$ ). The overall monthly collection trend for stomoxyines did not statistically significantly $(F=1.05 ; \mathrm{P}>0.05)$ fluctuate with collection months. Moreover, Maximum catches were observed in August (19\%) while minimum catches occurred in February (1\%) (Fig. 2).

It was noticed that no single species of tabanids was present throughout the prospection months. The ADT of certain species differed significantly during the collection months and sites. Thus, T. taeniola was most abundant in February and November in Mbidjoro and Velambai; while in Vina du Sud, two abundance peaks were recorded for this species in March and December. The peak abundance of T. par occurred in March and May at Vélambaï and Vina du sud; while in Mbidjoro, it was observed in March and June. Meanwhile, the abundance peak of $C$. longicornis occurred in May and November in Mbidjoro, while in Vina du sud, it was observed in August and December. The highest tabanid species richness (seven species) was noticed in June; while July and August recorded the lowest species richness (one species). The Margelef index was highest in June (3.74) as compared to zero recorded for July and August.

The ADT of stomoxyines fluctuated with months and sites. S. n. niger and S. calcitrans showed abundance peaks in May in all the sites and in March at Mbidjoro and Vina du sud. S. omega showed its peak abundance in August at Vélambaï and Vina du sud; while in Mbidjoro, its abundance peak was noticed in September. The species diversity index of stomoxyines was very high in December (1.47) as compared to 0.72 obtained in February.

\section{Seasonal variation of stomoxyines and tabanids in the forest}

The ADT of stomoxyines differed significantly with collection seasons ( $F=6.76 ; \mathrm{P} \otimes 0.05)$ where they were very abundant in the rainy season $(100.77 \mathrm{f} / \mathrm{t} / \mathrm{d})$ (Fig. 3a). All the species of stomoxyines occurred in both seasons, but it was noticed 
that the ADT of $S$. $n$. niger $(F=5.83 ; \mathrm{P} \otimes 0,05)$ and $S$. omega $(F=8.04 ; \mathrm{P} \otimes 0.05)$ were statistically significantly higher. The Margelef index was 0.79 in the dry season and 0.65 in the rainy season.

The ADT of tabanids statistically significantly differed with collection seasons ( $F=10.82 ; \mathrm{P} \bigotimes 0.05)$ and were most abundant during the dry season $(21.08 \mathrm{f} / \mathrm{t} / \mathrm{d})$ (Fig. 3b, c, d). The ADT of tabanids across seasons was not uniformly distributed. Certain species were caught in both seasons notably T. taeniola, T. parand T. socius and were most abundant in the dry season; while $C$. longicornis, $C$. dimidiata and $C$. silacea as well as $A$. fasciata were most abundant in the rainy season. $T$. latipes and $H$. decora were caught in the rainy and dry season respectively. For tabanids, the Margalef index was 2.26 in the rainy season and 1.78 in the dry season.

\section{Seasonal variation of stomoxyines and tabanids in the savanna}

The ADT of stomoxyines did not differ significantly with collection seasons $(\mathrm{t}=1.19 ; \mathrm{P}>0.05)$. S. xanthomelas $(\mathrm{P} \otimes 0.05 ; F$ $=6.05 ; 0.26 \mathrm{f} / \mathrm{t} / \mathrm{d})$ and $S$. omega $(P \otimes 0.05 ; F=4.36 ; 2.16 \mathrm{f} / \mathrm{t} / \mathrm{d})$ were significantly most abundant in the rainy season (Fig. 4a). All the stomoxyines species were caught in both seasons except $S$. inornatus that was only captured in the dry season. For stomoxyines, the Margalef index was 1.22 in the dry season and 0.82 in the rainy.

The ADT of tabanids differed statistically with collection seasons $(F=6.43 ; \mathrm{P} \otimes 0.05)$ and was most abundant in the dry (2.58) season. At the species level, T. taeniola (P区0.05; $F=12.4 ; 1.01 \mathrm{f} / \mathrm{t} / \mathrm{d}$ ) and $C$. distinctipennis (Pख0.05; $F=6.89 ; 0.16$ $\mathrm{f} / \mathrm{t} / \mathrm{d}$ ) (Fig. 4b, c) were statistically significantly higher in the dry season. All the species of tabanids occurred in two seasons except $T$. fasciatus that was only caught in the dry season (Fig. 4b). For tabanids, the Margalef index was 2.84 in the rainy season and 1.9 in the dry.

\section{Influence of weather parameters on the monthly distribution of Stomoxys and tabanids}

For stomoxyines in the forest, an increase in temperature led to the reduction in their ADT. It was observed that the high temperature recorded in February and October led to the reduction in the ADT of forest stomoxyines; while a reduction in temperature from April led to an increase in the ADT of forest stomoxyines (Fig. 5a). Generally, there was a negative and significant correlation $(r=-0.943 ; p<0.05)$ between monthly stomoxyines ADT and temperature in the forest. It was noticed that increase in humidity led to an increase in the ADT of stomoxyines and this was noticed from April to August; while a decrease in humidity led to the reduction in the ADT of forest stomoxyines and occurred from September to December (Fig. 5a). There was a positive and significant correlation $(r=0.920 ; p<0.01)$ between monthly stomoxyines ADT and humidity in the forest. An increase in rainfall led to an increase in the ADT of forest stomoxyines and this occurred from July to September (Fig. 5a). There was a positive and significant correlation $(r=0.625 ; p<0.01)$ between monthly stomoxyines ADT and rainfall in the forest. For tabanids in the forest, their abundance was observed in November and December where their abundance was favoured by an increase in temperature (Fig. 5b). Generally, there was a positive and significant correlation $(r=0.720 ; p<0.05)$ between monthly tabanids ADT and temperature in the forest. The increase in humidity from May to October reduced the abundance of tabanids (Fig. $5 \mathrm{~b}$ ). There was a negative and significant correlation $(r=-0.819 ; p<0.05)$ between monthly tabanids ADT and humidity in the forest. Low precipitation led to an increase in the ADT of forest tabanids from March to May and October; while high precipitation in June reduced their ADT. There was a negative and non-significant correlation $(r=-0.547 ; p>0.05)$ between monthly tabanids ADT and humidity in the forest.

For savanna stomoxyines, a decrease in temperature from April to October led to an increase in the ADT of savanna stomoxyines (Fig. 5 c). Generally, there was a negative and non-significant correlation $(r=-0.355 ; p>0.05)$ between monthly stomoxyines ADT and temperature in the savanna. An increase in humidity in March led to an increase in the

Page 10/21 
ADT of savanna stomoxyines; while a decrease in the humidity from October led to a decrease in their ADT (Fig. 5c). There was a positive and significant correlation $(r=0.649 ; p<0.01)$ between monthly stomoxyines ADT and humidity in the savanna. It was noticed that an increase in rainfall from April to September led to an increase in the ADT of savanna stomoxyines (Fig. 5c). There was a positive and non-significant correlation ( $r=0.503 ; p>0.05)$ between monthly stomoxyines ADT and humidity in the savanna. For savanna tabanids, an increase in temperature led to an increase in their ADT and this occurred in March (Fig. 5d). Generally, there was a positive and significant correlation $(r=0.764$; $p<$ 0.05 ) between monthly stomoxyines ADT and temperature in the savanna. An increase in humidity led to the reduction in the ADT of savanna tabanids and was like the case of July where humidity was highest (Fig. $5 \mathrm{~d}$ ). There was a negative and significant correlation $(r=-0.659 ; p<0.01)$ between monthly stomoxyines ADT and humidity in the savanna. High precipitation led to a decrease in the ADT of savanna tabanids and this happened when rainfall started increasing in April and led to the reduction in their ADT (Fig. $5 d)$. There was a negative and significant correlation $(r=-0.579 ; p<0.01)$ between monthly stomoxyines ADT and rainfall in the savanna.

\section{Discussion}

This present trial constitutes the first available data on a comparative longitudinal study on tabanids and stomoxyines in the rainforest and Guinee-savanna of Cameroon. Stomoxyines were more abundant than tabanids and this finding corroborates with the finding of Mounioko et al. [19] in Campo in the rainforest of South Cameroon and Sevidzem et al., [15]. Lendzele et al. [16] in Sora-Mboum in the Sahel savanna of North Cameroon. High catches were recorded despite the limited number of traps and this could be explained by the positive influence of the different odor-baited traps used, variation in the prospected sites and long duration of trapping (12 months). In fact, the use of artificial odorants (Octenol) could significantly increase the catches of tabanids and stomoxyines [32-33].

In the forest, stomoxyines were the most abundant and least diversified group during the study. Four species were identified and were like those identified by Kutomy et al. [34] in the tropical forest of North Gabon and Mounioko et al. [19] in the tropical rainforest of South Cameroon. In the Guinee-savanna zone, five Stomoxys spp. were identified with one, known as $S$. inornatus present in the savanna that was not identified in the forest. Sevidzem et al. [15] identified four species of stomoxyines in the Sahel savanna of North Cameroon. On the contrary, Mihok et al. [35] in the forest of Kenya and Mavoungou et al. [7] in the forest of Gabon signaled nine and seven species respectively. This contradiction in the species composition can be due to the different climatic conditions in the different prospection countries. The high relative abundance of $S$. $n$. niger in both forest and savanna zones has already been signaled by several reports in Cameroon and elsewhere [7-36-34-10-19-16].

Tabanid flies were less abundant, but with high specifies richness. In fact, 12 tabanid species were identified in the forest and grouped under four genera notably Tabanus, Chrysops, Haematopota and Ancala. The genus Tabanus was the most dominant and the genus Ancala was least represented. The genera composition of tabanids recorded in the rainforest during the study is like that reported by Mavoungou et al. [8] who found a high abundance of the individuals of the genus Tabanus and weak abundance of the individuals of the genus Ancala. In the savanna, 10 species were identified and regrouped under five genera with Atylotus inclusive but absent in the forest. This genera composition in the savanna was like that reported in Ivory Coast [5-6] and in North Cameroon [17]. The restriction of the genus Atylotus in the savanna zone in the present study was contradictory to that of Zinga et al. [36] that signaled Atylotus in the forest. The presence or absence of the genus Atylotus in the various studies could be due to the differences in the micro-climatic conditions of the different study sites in the different study areas. The total number of species that constituted the tabanids fauna of our study sites was far lower than 60 species obtained in the forest zone of Cameroon [12] as well as more than 80 species reported for the whole of Cameroon [13]. The low species numbers obtained in the present study as compared to the previous ones can be explained by the changes in the environmental conditions that have undergone some modifications during the last decades, climate change that have led to the extinction of many species as well as the re-

Page $11 / 21$ 
emergence of new species and the fact that this study was only carried out in two out of the five agro-ecological regions of Cameroon. T. taeniola was the most abundant tabanid species. This result is like that of Zinga et al. [36]. The high frequency of $T$. taeniola in the Tabanidae collections of our study was contrary to the report in Mauritania [37] and in Chad [38] who rather obtained Atylotus agrestis as the dominant species in the savanna, that was rare in the savanna zone and absent in the list of tabanids from forest in the present study. The discrepancy could be explained by the differences in the geographical location of the study sites of the different studies. It was interesting to know that $C$. longicornis was caught in the forest and savanna, Chrysops distinctipennis was only found in the savanna. Similarly, $C$. dimidiata and $C$. silacea were forest restricted and was reported to be present in the rainforest of south Cameroon [19].

Stomoxys species differed with sampled sites in the forest. This could be due to the variation in landscape and structures of the micro-environments [9]. Maximum catches of stomoxyines were recorded at the abattoir. In fact, this site is situated at the suburbs of the village and is characterized by human settlement, domestic animals and pasture, which could favor the development of stomoxyines since the surroundings of animal stables and slaughterhouses are known to constitute their breeding environment [39]. Moreover, the vegetation cover in the study area was open enough as compared to other sites, which improved its luminosity, which is a necessary factor for the infestation of a milieu by stomoxyines. The presence of all the four Stomoxys spp. in the three environments could be accounted for by the presence of vertebrate hosts [40] in the study area. In fact, the presence of cattle and other domestic animals at the abattoir and palm oil plantation together with wildlife in the game reserve, constituted important blood meal host for stomoxyines [41]. The abundance of tabanids in the different sites of the forest zone indicated that tabanids were most frequent around the palm oil plantation and scanty at the abattoir. The high frequency in the palm oil plantation was because of the presence of dense vegetation, high humidity, high illumination, Ndama cattle breeds (source of blood meal), marshy land (breeding ground for tabanids) and less inhabitation that favoured the development, activity and survival of tabanids. Certain species such T. taeniola and T. parwere present and abundant in all sampled sites. This could be explained by their ability to adapt in different micro-habitats [38]. In addition, other species such as T. argenteus, T. latipes and Tabanus sp. infested only the palm oil plantation, and this could be due to ecological preference for this site and their low adaptive capacities to the other environments (abattoir and game reserve).

The five species of stomoxyines in the savanna occurred in all the trapping sites except for $S$. inornatus which was only recorded in Vina du sud. The capture of $S$. inornatus in the savanna was contrary to the observation made in Kenya [35] and in Gabon [8] who considered that this species was highly frequent in the forest where the human density is low and high presence of breeding substrates. The savanna biotope recorded lower catches as compared to the forest. This is because the forest sites were located near sea level (approx. $35 \mathrm{~m}$ a.s.l) which could be favorable for Stomoxys survival and diversity as compared to the savanna site which was elevated at an altitude above $1000 \mathrm{~m}$ a.s.I which might reduce the survival rate of stomoxyines. For tabanids, T. fasciatus and A. fasciata were only trapped at Vina du sud. This site did not only harbor rare species, but equally recorded the highest number of tabanid catches in the savanna. The reason for this catch in the zone is because the area consists of several marshy lands that favoured the breeding of tabanids including rare species which could not be found in other sites due to lack of such suitable developmental substrates. The occurrence of high numbers of tabanids around marshy grounds has already been confirmed in the far north region of Cameroon [17]. There was high species diversity of tabanids in Mbidjoro due to the occurrence of different vegetation types (open grass savanna, secondary forest and gallery forest), rivers and cattle that enhanced their survival.

The ADT of stomoxyines was not identical with the prospection months in the forest and was influenced by temperature, humidity and precipitation. The study of the monthly abundance of stomoxyines [42-43] showed a unimodal monthly distribution and was like the monthly distribution pattern obtained in this study with peak abundance noticed in August. The low abundance of stomoxyines observed in January could be related to the mean temperature of $28^{\circ} \mathrm{C}$ and relative humidity of $62 \%$. Whereas the peak abundance in August was related to the weak temperature, high temperature and rainfall. Taylor et al. [44] in Nebraska and Semelbauer et al. [45] obtained similar results with activity of Stomoxys 
moderately influenced by weather variables. S. n. niger was highly recurrent in all the collection months with peak in May, July and September in the Game reserve, palm oil plantation and abattoir respectively. The highest diversity of stomoxyines occurred in August (rainy season). For tabanids, peak catches occurred in December and lowest in August. August characterize heavy rain fall that led to flooding hence, causing the destruction of the breeding sites of tabanids as compared to December which is a transition period from rainy season to dry season that was characterized by ambient humidity required for their development. In December, T. parwas present in all sites, while $C$. longicornis occurred in all sites in April. Tabanus latipes and T. argenteus were only present in June and May respectively in the palm oil plantation. It could be retained that the species-specific propensity for each month and site could be linked to the availability of food, breeding sites and favorable weather conditions (temperature, humidity and rainfall) that support their development and survival. The different species of tabanids are adapted well to a wide range of climatic conditions [23]. In our study, the low abundance of tabanids obtained in August could be related to the high humidity (76\%) and low temperature of $24^{\circ} \mathrm{C}$. Whereas, the high abundance of tabanids observed in December could be due to the high temperature $\left(27.4^{\circ} \mathrm{C}\right)$ and low relative humidity $(61 \%)$ which favoured their activity and survival in the course of this month.

It was noticed that the monthly distribution of stomoxyines in our present study was trimodal with peak in March, May and August. This observation was contrary to that of [46] who rather showed that in warm regions the monthly distribution of stomoxyines is bimodal. This monthly variation in the distribution of stomoxys is linked to meteorological variables with high influence of humidity, weak influence of temperature and rainfall in the savanna region. The monthly activity of the different species of stomoxyines differed with capture sites and could be due to the specific characteristics of each milieu i.e. landscape and nature of the microenvironment [47]. The ADT of tabanids in the savanna varied with prospection month and influenced by climatic factors such as temperature, humidity and rainfall. The peak abundance of tabanids was noticed in March and corroborated with the observation of Acapovi et al. [5]. This peak abundance in March was characterised by the absence of rainfall, high temperature $\left(32^{\circ} \mathrm{C}\right)$ and weak humidity $(27 \%)$. This finding was in similitude with that of Raymond [48]. The monthly activity of tabanids differed with prospection sites. This observation was similar to that of Baldachino et al. [21] who reported that each trapping site possessed characteristic weather variables that influenced tabanid species abundance and distribution.

The abundance of stomoxyines differed with season. The peak development season for stomoxyines was in the rainy season. This could be explained by a high affinity of stomoxyines for humid areas [28-36]. Besides, high temperatures and low humidity of the dry season hindered the development of stomoxyines.

For tabanids, their peak abundance was noticed during the dry season. This is because of the recent interruption in precipitation that creates climatic conditions that favors the emergence of adults. In fact, during the rainy season, rainfall and cold are limiting factors for the activities of tabanids since such factors can lead to temporary dormancy of larval populations [30 - 10]. In contrast, Dia et al. [37] in Mauritania and Zinga et al. [36] in Gabon reported highest catches of tabanids during the rainy season.

The occurrence of two major Tabanidae taxonomic groups (Chrysops and Tabanus) in the forest and savanna zones indicate the potential risk for the spread of bovine trypanosomosis to the Ndama present in the palm oil plantation in the forest and zebu Goudali in Ngaoundere in the Guinee-savanna. This fact can be supported by the findings of researchers from neighboring countries working on the same subject. The report of Mounioko et al. [49] in the savanna and forest of Gabon indicates 60 to $100 \%$ infection rate of S. n. niger, S. omega and C. Iongicornis with Trypanosoma simiae tsvavo, T. simiae, T. congolense and T. theileri. All the listed stomoxyines and tabanids were caught in the forest and savanna of our present study. The dominant nature of Tabanus species notably T. par and T. taeniola in our collection were detected positive with $T$. congolense, T. theileri and other haemoparasites in flies from Zambia and South Africa [11], indicating possible detection of such Trypanosoma spp. in our samples. However, Stomoxys spp. were detected positive for $T$.

Page 13/21 
evansi and T. congolense by [50]. Parasitological and molecular screening of stomoxyines and tabanids for Trypanosoma species is underway to define their potential to mechanically transmit trypanosomes and other haemoparasites.

\section{Conclusion}

The present study provides data on the longitudinal follow-up of the distribution of the stomoxyines and tabanid flies population in the different sites/season in the rain forest of Sanaga and Guinee-savanna of Ngaoundere. The forest sites were densely infested with four species of stomoxyines and twelve species of tabanids, while the savanna sites were densely infested with five species of stomoxyines and ten species of tabanids. High species numbers were encountered in the forest, but high species diversity and uniform distribution occurred in the savanna. Landscape, season and weather parameters like temperature, humidity and rainfall in the different sites greatly influenced the distribution and occurrence of tabanids and Stomoxys. The occurrence of Chrysops, Tabanus and Haematopota in both sites is an indication of the possible mechanical transmission risk of bovine trypanosomosis. The exploitation of this information would enable the elaboration of control strategies for stomoxyines and tabanids in the forest and savanna regions of Cameroon.

\section{Abbreviations}

A.S.L: Above sea level; ADT: Apparent Density per Trap; DEFR: Douala-Edea Forest Reserve; EDI: Equity Distribution Index; F/T/D: Flies per Trap and Day.

\section{Declarations}

\section{Acknowledgements}

Authors thank the indigenes of Mouanko and the authorities of the Douala-Edea forest reserve for providing field assistance in the transportation of traps and trapping. We are grateful to the Special Mission for the Eradication of Glossines (MSEG) in Ngaoundere for providing the traps used in this study.

\section{Authors' contributions}

NEN, ADS, VDH, OL, AM and SLS conceived the study. ADS and SLS performed the systematic literature search. ADS and SLS wrote the manuscript. NEN, AM, LTK and CA jointly supervised the project. All authors read and approved the final manuscript.

\section{Funding}

Not applicable.

\section{Availability of data and materials}

All data generated or analyzed during this study are included in this manuscript.

\section{Ethics approval and consent to participate}

Not applicable.

\section{Consent for publication}


Not applicable.

\section{Competing interests}

The authors declare that they have no competing interests.

\section{References}

1. Melhorn JM, Ackerman WE. Guide of the evaluation of disease and injury causation. Am. Med. Assoc. 2010 . p. 456.

2. WHO. Weekly epidemiological record-Relevé épidémiologique hebdomadaire; 2006. p. 11.

3. Duvallet G, Boulanger N, Robert V. Arthropods: Definition and Medical Importance. Chapter 2. In Skin and Arthropod Vectors. Elsevier Inc.; 2018. p. 29-51.

4. Krinsky WL. Animal disease agents transmitted by horse flies and deer flies. J. Med. Entomol. 1976; 13: 225-274.

5. Acapovi GL, Yao Y, N'goran E, Dia ML, Desquesnes M. Relative abundance of tabanids in the savanna regions of Côte d'Ivoire. Elev. Méd. Vét. Pays Trop. 2001; 54: 109-114.

6. Acapovi-Yao GL, Kohagne TL, Tra Bi Ta D, Mavoungou JF. Dynamique et dispersion spatiale des Tabanidae dans différents faciès écologiques de Korhogo en Côte d'Ivoire. Entomol. Faun-Faun Entomol. 2017; 70 :3-22.

7. Mavoungou JF, Jay-Robert P, Gilles J, Atsame Edda A, Gerard D. Ecologie des stomoxyines (Diptera: Muscidae) au Gabon Premier inventaire dans différentes zones écologiques. Parasite. 2008; 15: 27-34.

8. Mavoungou JF, Makanga B, Acapovi YG, Desquesnes M, M’batchi B. Chorologie des Tabanidae (Diptera) dans la réserve de Biosphère Ipassa Makokou (Gabon) en saison des pluies. Parasite. 2012; 19: 165-171.

9. Bitome Essono PY, Dechaume-Moncharmont FX, Mavoungou JF, Obiang MR, Duvallet G, Bretagnolle F. Distribution and abundance of hematophagous flies (Glossinidae, Stomoxys, and Tabanidae) in two national parks of Gabon. Parasite. 2015; 22: 23.

10. Doumba NAG, Zinga KCR, Mounioko F, Maroundou AP, Nguema MO, Acapovi GLY, et al. Contribution à l'étude des Stomoxes et Tabanides, vecteurs mécaniques des trypanosomoses, dans la région de Ndendé au sud du Gabon. Faun. 2016; 69:111-123.

11. Taioe MO, Makhosazana YM, Namangala B, Chota A, Nthatisi IM, Musinguzi SP, et al. Characterisation of tabanid flies (Diptera: Tabanidae) in South Africa and Zambia and detection of protozoans parasites they are harbouring. Cambridge Univ. Press Parasitol. 2017; 144: 1162-1178.

12. Rageau J, Grenier P, Adam JP. Tabanidae du Cameroun Français. Ann. parasitol.1955: 30: 243-272.

13. Ovazza M, Mouchet J, Rxckenbach A. Tabanidae du Cameroun : II. Les espèces connues et leur répartition. Cahier. O.H.S.T.O.M., série. Entomologie. Méd Parasitol. 1970; 8: 323-351.

14. Sevidzem SL, Mamoudou A, Woudamyata AF, Zoli PA. Contribution to the knowledge of ecodiversity and density of tsetse (Glossinidae) and other biting flies (Tabanidae and Stomoxyinae) in the fly controlled-infested livestock/wildlife interface of the Adamawa plateau-Cameroon. J. Entomol. Zoo. Stud. 2015; 3: 329-333.

15. Sevidzem SL, Mamoudou A, Acapovi YGL, Achiri M, Tchuinkam T, Zinga KCR, et al. First Inventory of Non-biting and Biting Muscids of North Cameroon. Res. J. Biol. Sci. 2016; 5: 12-20.

16. Lendzele SS, Abdoulmoumini M, Lydie AY. Spatial repartition of tabanids (Diptera: Tabanidae) in different ecological zones of North Cameroon. Biodivers. Int. J. 2017; 1: 64-68.

17. Mamoudou A, Marcelin M, Suh PF, Lendzele S, Oumarou F, Garabed R, et al. Tabanid (Diptera: Tabanidae) fauna composition in different sites and biotopes of far-north, Cameroon. J. Biol. Nat. 2016; 6:146-154.

18. Sieumeni DA, Kohagne TL, Abah S, Fako HGC, Nukenine EN. Composition des espèces et dynamique des populations des vecteurs de trypanosomoses animales africaines à Dodéo, Adamaoua, Cameroun. 4th life Science

Page $15 / 21$ 
Conference, Dschang, Cameroon. 2014.

19. Mounioko F, Mavoungou JF, Zinga KCR, Engo PC, Koumba AA, Maroundou AP, et al. Etude préliminaire des vecteurs mécaniques des trypanosomes dans la localité de Campo et ses environs (sud-ouest du Cameroun). Entomol. 2017; 70: $95-105$

20. Gibson G, Torr SJ. Visual and olfactory responses of haematophagous Diptera tohost stimuli. Vet. Entomol. 1999; 13: $2-23$

21. Baldacchino F, Porciani A, Bernard C, Jay-Robert P. Spatial and temporal distribution of Tabanidae in the Pyrenees Mountains: influence of altitude andlandscape structure. Entomol. Res. 2013b; 104 :1-11.

22. Baldacchino F, Desquesnes M, Mihok S, Foil LD, Duvallet G, Jittapalapong S. Tabanids: Neglected subjects of research, but important vectors of disease agents! Infect. Genet. Evol. (Article in press); 2014.

23. Tamás H, Dénes $S$, Miklós $B$, András $B$, Mónika G, Róbert F, et al. The effect of weather variables on the flight activity of horseflies (Diptera: Tabanidae) in the continental climate of Hungary. Parasitol. Res. 2015; 114:1087-1097 DOI 10.1007/s00436-014-4280-3.

24. Godwin RM, Mayer DG, Brown GW, Leemon DM, James PJ. Predicting nuisance fly outbreaks on cattle feedlots in subtropical Australia. Pdn. Sci. 2017; http://www.publish.csiro.au/AN/justaccepted/AN16112.

25. Nga NE, Pouka KC, Boumsong NCP, Dibong DS, Mpondo ME. Inventaire et caractérisation des plantes médicinales utilisées en thérapeutique dans le département de la Sanaga Maritime: Ndom, Ngambe et Pouma. Appl. Biosci. 2016; 106:10333-10352.

26. CWCS. CWCS Douala-Edea forest project. Report of activities/ rapport d'activité 2005. Cameroon Wildlife conservation society, Mouanko; 2006. p.42.

27. Rippstein G. Etude de la végétation de l'Adamaoua. Evolution, conservation, régénération et amélioration d'un écosystème pâturé. Maisons-Alfort, France, Cirad lemvt; 1985. p.74.

28. Zumpt F. The Stomoxyinae biting flies of the world. Taxonomy, biology, economic Importance and control measures. Gustav Fischer Verlag, Stuttgart; 1973.

29. Surcouf JM, Ricardo G. Etude monographique des tabanides d'Afrique. Masson et Cie (Paris); 1909. p. 292.

30. Desquesnes M, Dia ML, Acapovi GL, Yoni W. Les vecteurs mécaniques des trypanosomoses animales. Editions Cirdes, 2005. p. 67.

31. Legendre L, Legendre P. Ecologie numérique. Le traitement multiple des données écologiques. Masson, Paris et les Presses de l'Université du Québec, Montréal; 1979. p. 197.

32. Djiteye A. Aperçu sur l'efficacité comparative de différents pièges et odeurs contre les mouches piqueuses (Diptera: Tabanidae et Muscidae) d'importance vétérinaire. In: $1^{\text {er }}$ Séminaire international sur les trypanosomoses animales non transmises par les glossines, Annecy, France; Octobre1992.p.14-16.

33. Mihok S, Maramba O, Munyoki E, Kagoiya J. Mechanical transmission of Trypanosoma by African Stomoxyinae (Diptera: Muscidae). Trop. Med. Parasitol. 1995; 46:103-105.

34. Kutomy POO, Zinga KCR, Mbang Nguema OA, Sembene PM, Mavoungou JF. Inventaire des mouches hématophages dans les élevages bovins, ovins et porcins à Oyem (Nord Gabon). Sci. 2014; 10: 373-381.

35. Mihok S, Clausen PH. Feeding habits of spp. stable flies in a Kenyanforest. Med. Vet. Entomol. 1996;10: 392-394.

36. Zinga-Koumba RC, Bouyer J, Mavoungou JF, Acapovi-Yao GL, Kohagne TL, Mbang Nguema OA, et al. Evaluation de la diversité des diptères hématophages dans une clairière marécageuse du Gabon à l'aide des pièges Vavoua et Nzi. Rev. Elev. Méd. Vét. Pays Trop. 2013; 66: 91-96.

37. Dia ML, Elsen P, Cuisance D, Diop C, Thiam A, Chollet JY. Abundance and seasonnal variations of tabanids in Southern Trarza (Mauritania). N. Y. Acad. Sci. 1998; 849: 456-460. 
38. Doutoum AA, Delafosse A, Elsen P, Amsler-Delafosse S. Vecteurs potentiels de Trypanosoma evansi chez le dromadaire au Tchad oriental. Rev. Elev. Méd. Vét. Pays Trop. 2002; 55: 21-30.

39. Mavoungou JF, Nguema RM, Acapovi GL, Koumba RZ, Mounioko F. Breeding Sites of Stomoxys spp. (Diptera: Muscidae), a Preliminary Study in the Makokou Region (North-East-Gabon). Vect. Biol. J. 2017; 2:1.

40. Foil LD, Gorham JR. Mechanical transmission of disease agents by arthropods. In: Eldridge B.F., Edman J.D. (eds). Kluwer Academic Publishers: Dordrecht, the Netherlands. Med. Entomol. 2000; 461-514.

41. Broce AB, Hogsette J, Paisley S. Winter feeding sites of hay in round bales as major developmental sites of Stomoxys calcitrans (Diptera: Muscidae) in pastures in spring and summer. J. Econs. Entomol. 2005. 98: $2307-2312$.

42. Masmeatathip R, Gilles J, Ketavan C, Duvallet G. First survey of seasonal abundance and daily activity of Stomoxys (Diptera: Muscidae) in Kamphaengsaen campus, Nakornpathom Province Thailand. Parasite. 2006, 13: $245-250$.

43. Sinshaw A, Abebe G, Desquesnes M, Yoni W. Biting flies and Trypanosoma vivax infection in three highland districts bordering lake Tana, Ethiopia. Parasitol. 2006; 142: 35-46.

44. Taylor DB, Berkebile DR, Scholl PJ. Stable fly population dynamics in eastern Nebraska in relation to climatic variables. J. Med. Entomol. 2007; 44:765-771.

45. Semelbauer M, Mangová B, Barta M Kozánek M. The Factors Influencing Seasonal Dynamics and Spatial Distribution of Stable Fly calcitrans (Diptera, Muscidae) within Stables. Insects. 2018; 142: 11.

46. Vazquez C, Mendoza IV, Parra MR, Garca VZ. Influence of temperature, humidity and rainfall on field population trend of calcitrans (Diptera: Muscidae) in a semiarid climate in Mexico. Parasitol. Lat. Am. 2004; 59: 99-103.

47. Salem A, Bouhsira E, Lienard E, Melou AB, Jacquiet P, Franc M. Susceptibilityof Two European strains of calcitrans (L.) to Cypermethrin, Deltamethrin,Fenvalerate, lambda-cyhalothrin, Permethrin and Phoxim. Int. J. Appl. Res. Vet. Med. 2012; 10: 249-257.

48. Raymond HL. Tabanus importunus, vecteur mécanique expérimental de Trypanosoma vivax en Guyane française. Parasitol. Hum. Comp. 1990; 6: 44-46.

49. Mounioko F, Gaël DM, Mavoungou JF, Zinga-Koumba CR, Aubin Armel Koumba, Sevidzem SL, et al. Molecular Screening of Trypanosoma spp. in Glossina, Stomoxys and Tabanids in the Moukalaba Doudou National Park (South-West, Gabon). World J. Vet. Sci. 2018; 6:52-61.

50. Sumba AL. Mechanical transmission of evansi and T. congolense by African Stomoxys spp. A thesis submitted in partial fulfillment for the degree of Master of Science (Medical and Veterinary Parasitology). University of Nairobi; 1997.

\section{Figures}




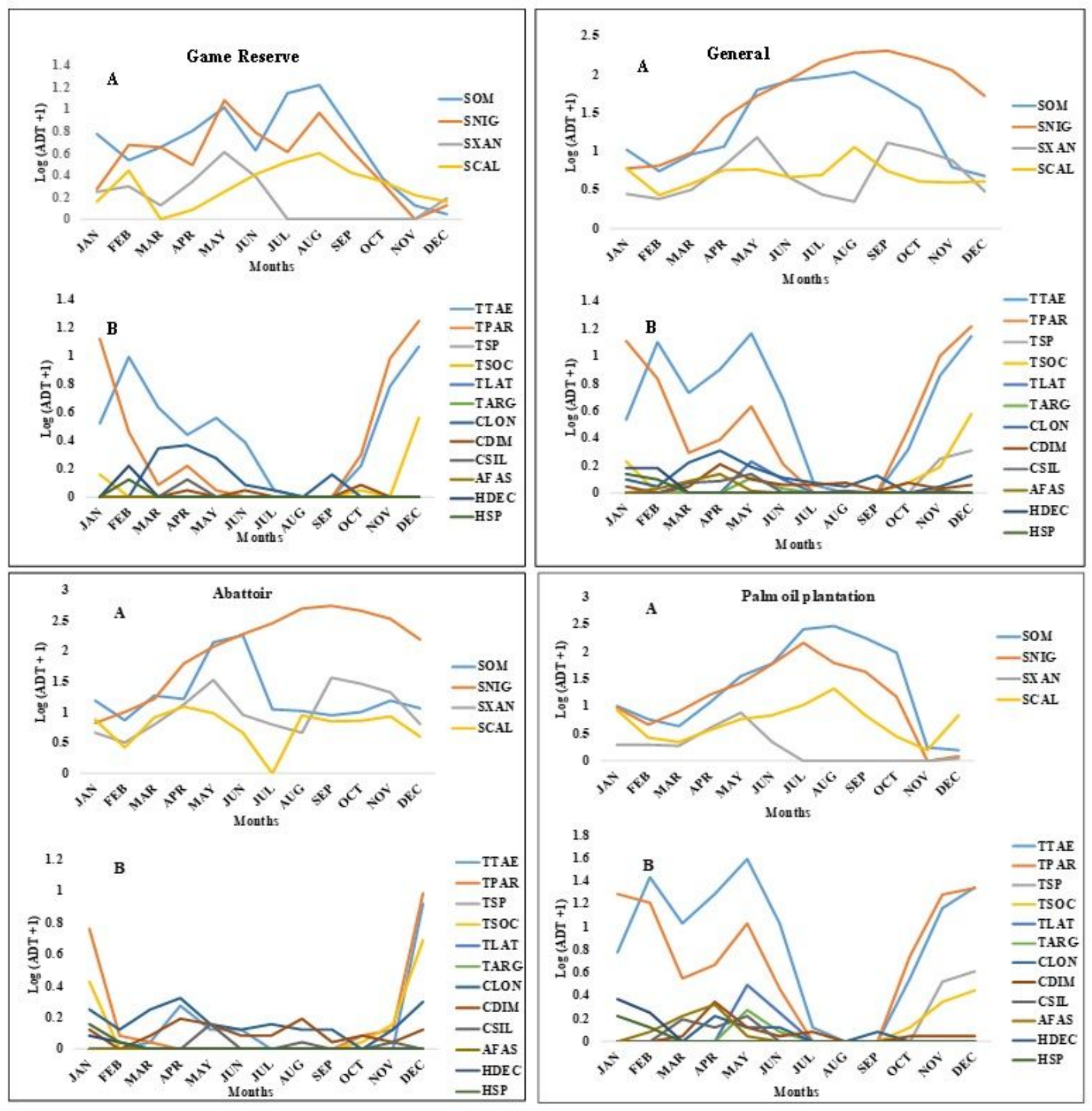

Figure 1

Monthly distribution of Stomoxys and tabanids in the forest: A stomoxyids and B tabanids. SCAL Stomoxys calcitrans, SNIG S. niger niger, SOM S. omega, SXAN S. xanthomelas. TTAE Tabanus taeniola, TPAR T. par, TSOC T. socius, TLAT T. latipes, TARG T. argenteus, CLON C longicornis, CSIL C. silacea, CDIM C. dimidiata, HDEC H. decora, HSP Haematopota sp non identified, TSP Tabanus sp non identified, AFAS Ancala fasciata. 


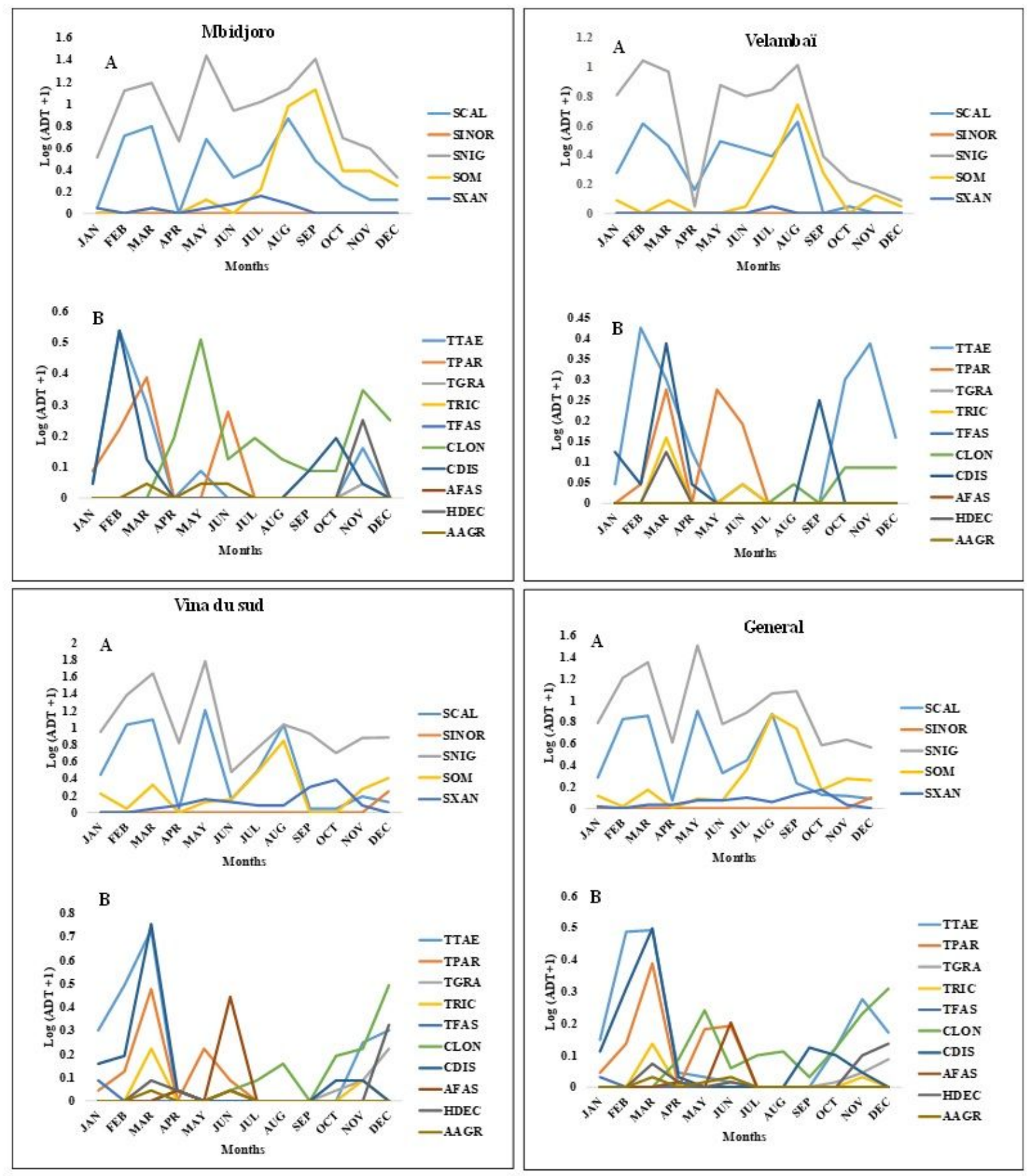

Figure 2

Monthly distribution of Stomoxys and tabanids in the savanna: A stomoxyids and B tabanids: SCAL Stomoxys calcitrans, SINOR S. inornatus, SNIG S. niger niger, SOM S. omega, SXAN S. xanthomelas. TTAE Tabanus taeniola, TPAR T. par, TGRA T. gratus, TRIC T. ricardae, TFAS T. fasciatus, CLON C longicornis, CDIS C. distinctipennis, HDEC H. decora, AAGR Atylotus agrestis, AFAS Ancala fasciata. 

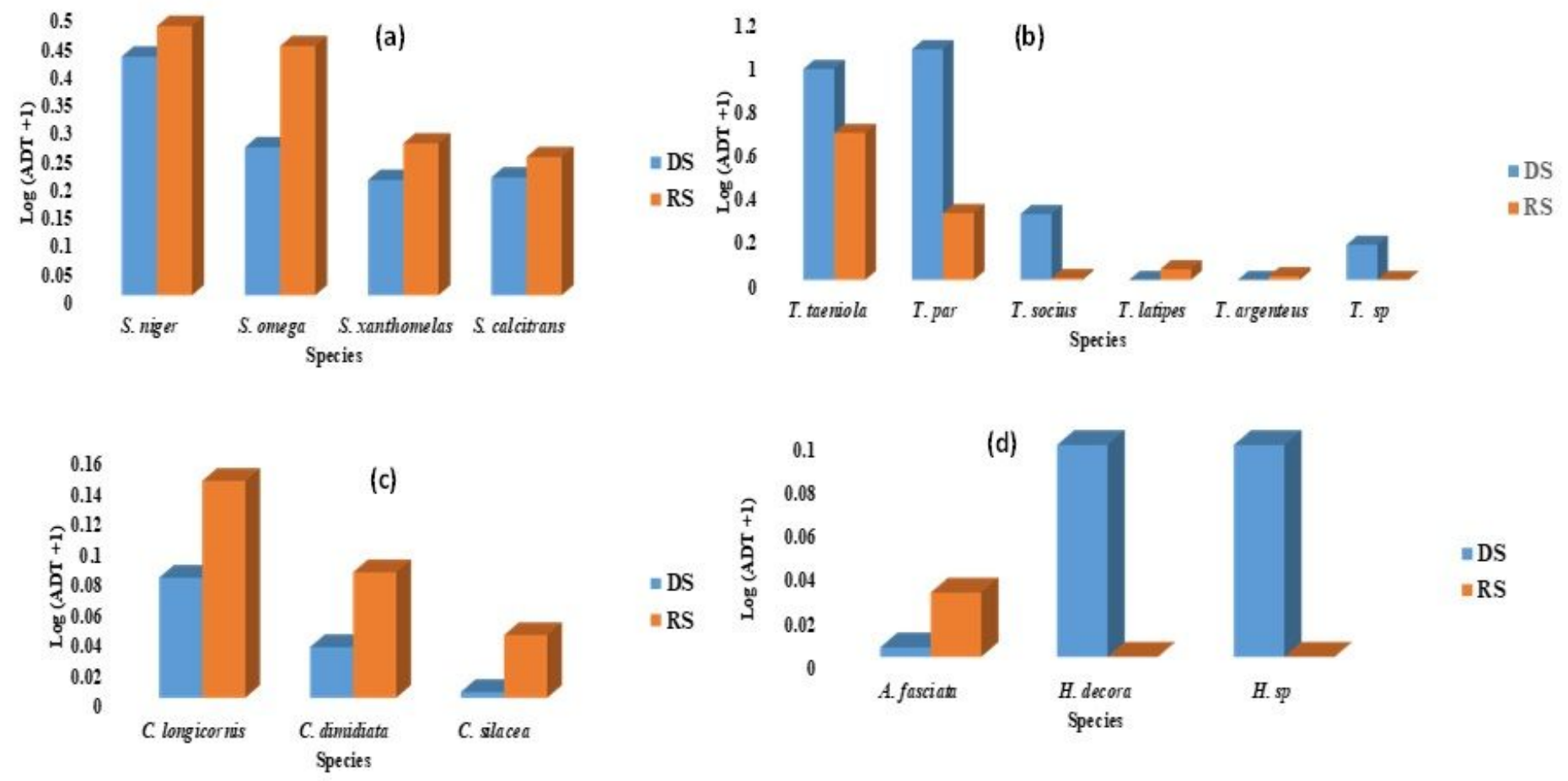

\section{Figure 3}

Seasonal apparent density of Stomoxys and tabanids in the forest: a) Stomoxys, b) Tabanus, c) Chrysops, d) Ancala and Haematopota, DS) dry season, RS) rainy season, H. sp) Haematopota species.

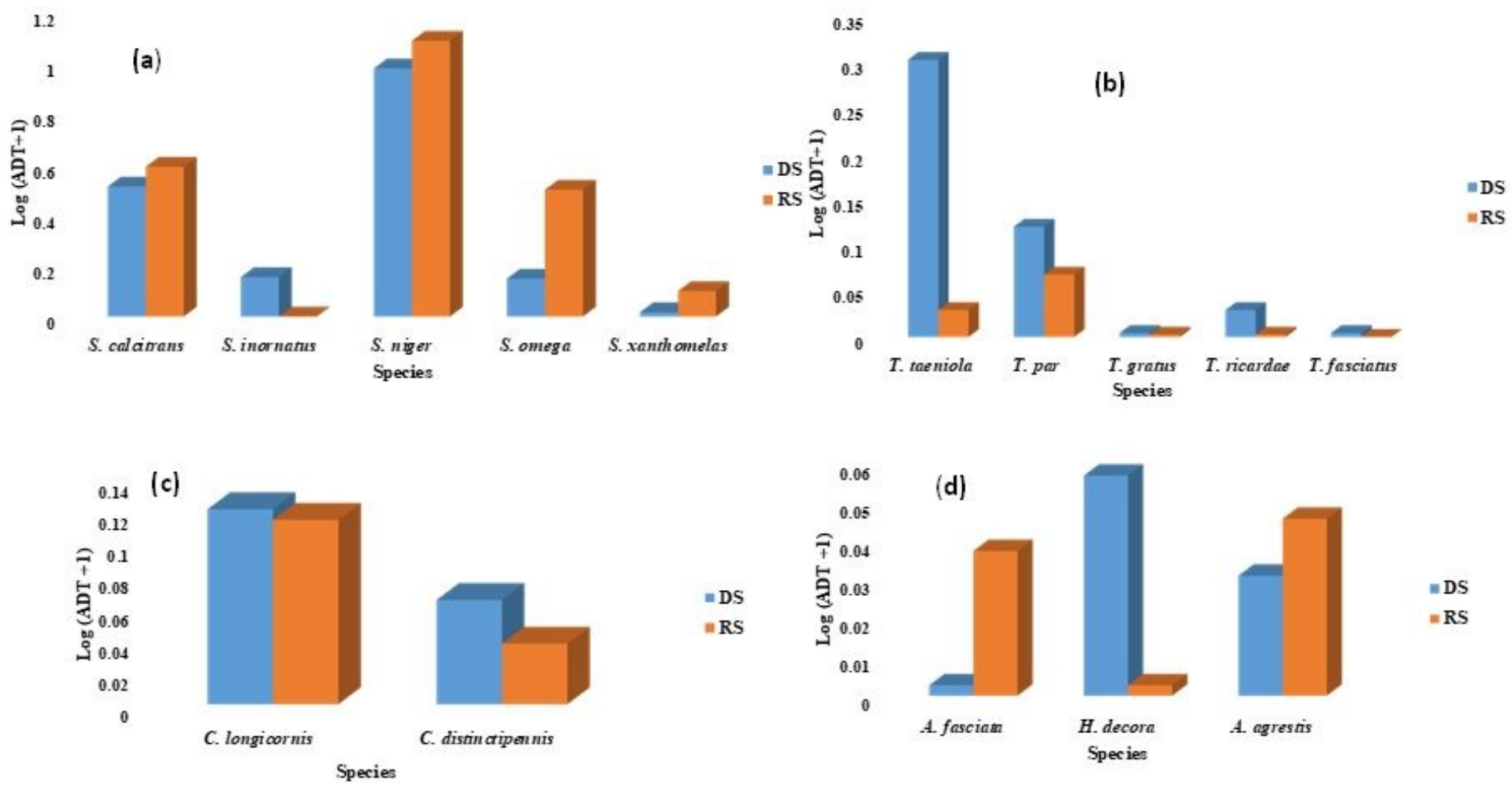

Figure 4 
Seasonal apparent density of Stomoxys and tabanids in the savanna: a) Stomoxys, b) Tabanus, c) Chrysops, d) Ancala, Haematopota and Atylotus, DS) dry season, RS) rainy season.
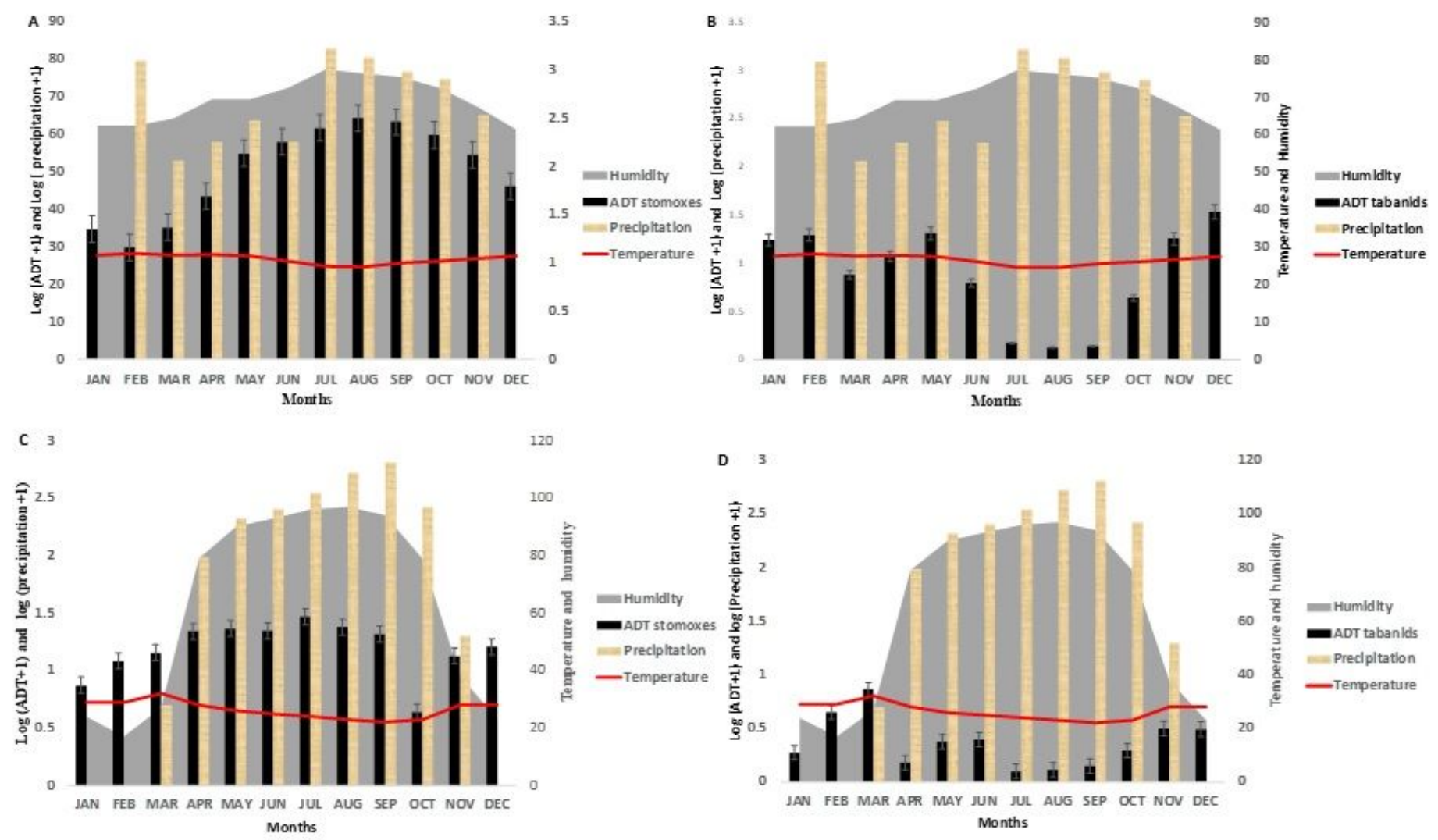

Figure 5

Influence of weather parameters on the monthly abundance of tabanids and stomoxes: A) Stomoxys in forest, B) tabanids in forest, C) Stomoxys in savanna and D) tabanids in the savanna, ADT: apparent density.

\section{Supplementary Files}

This is a list of supplementary files associated with this preprint. Click to download.

- graphicalabstract.docx 